\title{
Effect of Processing Techniques on the Degradability Characteristics of Acacia (Acacia hockii) Leaf
}

\author{
"ARUWAYO, A; SHEHU, TM; ADELEKE, RA; SALISU, US; JAMILU, YR \\ Department of Animal Science, Faculty of Agriculture and Agricultural Technology, Federal University, Dutsin-Ma, Katsina State, Nigeria \\ *Corresponding Author Email: aaruwayo@fudutsinma.edu.ng; Tel: +234-8035813377
}

\begin{abstract}
This experiment was conducted at the Federal University Dutsin-ma Livestock Teaching and Research Farm in Dutsin-ma Local Government area of Katsina State, Nigeria. The study was meant to ascertain the effect of processing techniques on crude protein (CP), acid detergent fiber (ADF) and neutral detergent fiber (NDF) degradation characteristics of three differently processed Acacia hockii leaf meal (ensiled (T1), sun dried (T2) and fresh (T30) incubated in the rumen of five rams at 3, 6, 12, 24 and 48hrs. Acacia hockii leaves were collected from Dutsin-ma town and used in the experiment as as fresh leaves, sun-dried and ensiled. Five rams with average live weight of $20 \mathrm{~kg}$ were fistulated and used as replicates in a completely randomized design (CRD). They were fed with groundnut haulms, maize offal and cowpea husk in a libitum at a ratio of $70 \%: 30 \%$ respectively along with other management practices. The results of the rumen degradation characteristics showed that there was a significant $(p<0.05)$ difference in the soluble fraction of crude protein, acid detergent fibre and neutral detergent fibre degradation among the treatments. There was also a significance $(p<0.05)$ difference between the outflow rates of effective crude protein digestibility, effective acid detergent digestibility and effective neutral detergent digestibility. It was concluded from the study that ensiling and drying methods of processing reduces the ant-nutritional factors and the consequent better degradability of T1 and T2. However, the results of the study also revealed that ensiling is more effective than drying hence the better degradability recorded of crude protein, neutral detergent fiber, acid detergent fiber and the effective passage rate.
\end{abstract}

\section{DOI: https://dx.doi.org/10.4314/jasem.v24i6.8}

Copyright: Copyright (C) 2020 Aruwayo et al. This is an open access article distributed under the Creative Commons Attribution License (CCL), which permits unrestricted use, distribution, and reproduction in any medium, provided the original work is properly cited.

Dates: Received: 14 October 2019; Revised: 16 May 2020; Accepted: 10 June 2020

Keyword: Digestibility, degradability, ensile, leaf

Forage is a plant material mainly plant leaves and stems eaten by grazing livestock (Fageria, 1997). Historically, the term forage meant only plants eaten by the animals directly as pasture, crop residue, or immature cereal crops, but it is also used more loosely to include similar plants cut for fodder and carried to the animals, especially as hay or silage (Fageria, 1997). Forage trees and shrubs are integral part of farming system and generally, have multiple uses in all less-developed countries in the tropics (Khamseekhiew et al., 2001).

They are available all the year round and possess nutritive value that can sustain the animals along with supplements (Aruwayo and Adeleke, 2019). Browse plants are rich in protein and its chemical composition tends to vary a little due to season when compared to grass (Lukhele and Van Ryssen, 2003). Acacia hockii is a browse shrub widely available and fed to animals by farmers in the tropics. Their use has been shown to enhance the performance of ruminants that depend on poor quality roughages resulting in improve growth rates and increase reproduction efficiency (Orden et al., 2000). However, the presence of toxic and some plant-secondary metabolite have been shown to significantly limit the use of browse plants in feeding ruminant animals. Hoste et al. (2006) reported that these constituents portend various harmful effects on the performance of the animals which include loss of appetite and decline of dry matter intake and proteins digestibility. In spite of the apparently high dry matter values of these browse plants, Azim et al., (2002) reported that animal response is not always predictable and there are differences in their nutritive values.

This could be due to hindrances to microbial activities by anti-nutritional factors like saponins, polyphenols, alcoholic glycosides and bound quinones (anthraquinones) as reported by Kamra et al. (2008).

There are reports of different processing methods that have been adopted to mitigate the effect of these antinutritional factors. This study then employed drying and ensiling methods to assess the effect of processing on the anti-nutritional contents of Acacia hocki leaf through evaluation of some degradability parameters. 


\section{MATERIALS AND METHODS}

Location of the Experiment: The study was conducted at the Teaching and Research Farm of Federal University Dustin-Ma, Katsina state. The Farm is located in Dutsinma Local Government area, about 5 Kilometres to the Take of Campus and almost $15 \mathrm{~km}$ to main campus. Dustin-ma lies between $12^{\circ} 27^{\circ} 18$ north, $7^{\circ} 29^{\circ} 29^{\circ}$ 'East. It experiences rainfall basically between May and September (Meteoblue Weather, 2017). The rainfall is around $600 \mathrm{~mm}$ per year and average temperature of $26.0^{\circ} \mathrm{C}$ (CLIMATEDATA.ORG, 2019). Much of the Sudanian Savanna region is used in the form of parklands, where useful trees, such as Shea, baobab, locust-bean tree and others are spared from cutting, while sorghum, maize, millet or other crops are cultivated beneath(Scott, 2013). The area has a prevalence of ruminant animals in the rural communities with an estimate population of 59,022 as at 2007(Scott, 2013).

Sample preparation: Acacia hockii leaves were collected from Dutsin-ma town and subjected to the following treatments:

Fresh leaves: Fresh leaves, immediately after collections were taken to the laboratory for analysis.

Sun-drying: The samples were air-dried under a shade at a temperature of $30^{\circ} \mathrm{C}$ for five days until when the leaves become crisp, the sample were then stored in airtight plastic bags until when needed for analysis.

Ensiling: Samples were collected and ensiled in an airtight polyethylene bags for seven days.

All samples were crushed to pass through $1 \mathrm{~mm}$ sieve and stored in plastic bottles before the laboratory analysis.

Animals and their management: Three rams with average live weight of $20 \mathrm{~kg}$ were fistulated and used as replicates in a completely randomized design (CRD) to determine in Sacco DM and OM degradability of the differently processed Acacia hockii leaf meal. The rams were quarantined for two (2) in individual pens and were fed with hay and concentrate $(14 \% \mathrm{CP})$ ad libitum at a ratio of $70 \%: 30 \%$ respectively. Water and mineral block were available at all times. The diets were offered in two equal meals at $08: 00 \mathrm{~h}$ and $16: 00 \mathrm{~h}$. The animals were adapted to the basal feed for a period of fourteen days, prior to the suspension of the bags in the rumen.

Ruminal Degradation Study: Rumen degradability was measured according to the techniques described by Ørskov (2000). Three grams of each sample was weighed into labeled weighed nylon bags with the size of $(70 \mathrm{~mm} \times 40 \mathrm{~mm}$; pore size of $0.2 \mathrm{~mm})$. The bags were tied firmly using nylon strings and anchored with about $25 \mathrm{~cm}$ nylon thread in the rumen of each the ram for each sample and each incubation time. The Incubation times were 3, 6, 12, 24 and 48hours. The 0 hrs incubation samples were soaked in warm water for $2 \mathrm{hrs}$ and washed in similar condition as in the other sample. Other bags containing undigested residues were sequentially removed from the rumen after each incubation time and thoroughly washed under running tap water until the washing water was clear. They were then dried at the temperature of $60^{\circ} \mathrm{C}$ for $48 \mathrm{hrs}$, cooled in a desiccators and the weight of residues recorded. For each feedstuff, degree of dry matter and organic matter degradation was plotted against incubation time and the curve drawn by hand.

The values of a ( $\%$ solubility) and $b$ (potentially degradable fraction) were determined from the graph. The steepest section of the curve (where the change $\mathrm{dy} / \mathrm{dt}$ was most rapid, indicating maximum rate of drymatter degradation) was identified and the percentage degradation $(\mathrm{P})$ and incubation time $(\mathrm{t})$ corresponding to the midpoint of this section were read; this enable the degradation rate constant $(\mathrm{C})$ to be calculated from the following exponential equation (Ørskov, 2000).

$$
P=a+b\left(1-e^{-c t}\right)
$$

Where: $\mathrm{P}=$ dry-matter degradation (\%); $\mathrm{a}=$ dry-matter solubility $(\%) ; b=$ potentially degradable fraction $(\%)$; $\mathrm{t}=$ time of maximum rate of dry matter degradation (hours); $\mathrm{c}=$ degradation rate constant.

Effective degradability (ED) of the samples was calculated using the outflow rates of $0.02,0.03,0.04$ and $0.05 / \mathrm{hr}$, according to (Ørskov et al., 1980) model:

$$
E D=a+(b c / c+k)
$$

Where ED is effective degradability; ' $a$ ', ' $b$ ' and 'c' are the constants as described earlier in the exponential equation (Ørskov, 2000) and ' $\mathrm{k}$ ' the rumen fractional outflow rate constant.

Laboratory Analyses: The dry matter content of feed, sample was determined by drying the samples at $60^{\circ} \mathrm{C}$ for 48 hours and then ash by incineration for 6hours at $550^{\circ} \mathrm{C}$. kjeldahl nitrogen analyses (AOAC, 2000) were performed in duplicate on dried feed, and $\mathrm{CP}$ calculated as ( $\mathrm{N} \times 6.25)$, crude fiber ( $\mathrm{CF}$ ) content by means of Foss Tecator Analyzer, ether extract content by Sortex system 1040 and ash content by combustion at $550^{\circ} \mathrm{C}$ in muffle furnace. 
Statistical analyses: Analysis of variance was carried out to determine the effects of processing methods on dry matter and organic matter degradation, Neutral Detergent Fiber, Acid Detergent Fiber, Effective passage Rate using the Proc. GLM procedure of SAS (SAS 2001).

Using the model

$$
Y_{i j}=\mu+T_{i}+e_{i j}
$$

Where $\mathrm{Y}_{\mathrm{ij}}=$ Record of the $\mathrm{J}^{\text {th }}$ value belonging to the $\mathrm{i}^{\text {th }}$ sample; $\mu=$ Overall mean; $\mathrm{T}_{\mathrm{i}}=$ Effect of the $\mathrm{i}^{\text {th }}$ incubation period $(0-48 \mathrm{~h}) ; \mathrm{e}_{\mathrm{ij}}=$ Error term

Treatment means that showed significant were separated using Duncan multiple range test (Duncan, 1995).

\section{RESULTS AND DISCUSSION}

Chemical composition of the feed: The chemical composition of the feed is presented in Table 4.1. There is significant $(\mathrm{p}<0.05)$ difference in dry matter of the fresh, dried and ensiled. There is also a significant $(\mathrm{p}<0.05)$ difference in the $\mathrm{CP}, \mathrm{CF}$, Ash, oil, tannin and saponin contents of the three treatments.

There is significant $(\mathrm{p}<0.05)$ difference in $\mathrm{CP}$ contents between the treatments. T3 (fresh leaves) had CP content of (12.95\%) and those of T2 (sun dried) and $\mathrm{T} 1$ (ensiled) had $14.65 \% 15.06 \%$ respectively. There is also a significant $(\mathrm{p}<0.05)$ difference in CF between the treatments. T3 (fresh leaves) had CF content of $(9.23 \%)$ and there is no significant $(p>0.05)$ difference between those of T2 (sun dried) and T1 (ensiled) had $5.71 \% 5.61 \%$. The ash content of T1 (1.29\%) and T2 $(1.47 \%)$ is not significantly $(\mathrm{p}>0.05)$ different but are lower than T3 $(2.35 \%)$. The tannin content is significantly $(\mathrm{p}<0.05)$ different between T3 $(0.06 \%)$ and those of T2 $(0.04 \%)$ and T1 $(0.04 \%)$ are not significantly $(\mathrm{p}>0.05)$ different, the saponin content of T1 $(9.00 \%)$ and T2 $(10.00 \%)$ are not significantly $(\mathrm{p}>0.05)$ different but are lower than T3 (16.00\%) which is the highest.

Table 1. Effects of processing on chemical composition of Acacia

\begin{tabular}{lllll}
\multicolumn{5}{c}{ hockii leaf $(\%)$. } \\
\hline Parameters & Ensiled & Dried & Fresh & SEM \\
\hline Dry matter & $75.00^{\mathrm{a}}$ & $89.70^{\mathrm{b}}$ & $63.33^{\mathrm{c}}$ & 1.896 \\
Crude protein & $15.06^{\mathrm{a}}$ & $14.65^{\mathrm{a}}$ & $12.95^{\mathrm{b}}$ & 0.474 \\
Crude fiber & $5.61^{\mathrm{a}}$ & $5.71^{\mathrm{a}}$ & $9.23^{\mathrm{b}}$ & 0.091 \\
Ash & $1.29^{\mathrm{a}}$ & $1.47^{\mathrm{a}}$ & $2.35^{\mathrm{b}}$ & 0.053 \\
NFE & 75.89 & 76.28 & 73.47 & 0.957 \\
Oil & 2.15 & 1.89 & 2.00 & 0.099 \\
\hline Tannin & $0.04^{\mathrm{a}}$ & $0.04^{\mathrm{a}}$ & $0.06^{\mathrm{b}}$ & 0.006 \\
Saponin & $9.00^{\mathrm{a}}$ & $10.00^{\mathrm{a}}$ & $16.00^{\mathrm{b}}$ & 0.577
\end{tabular}

$\mathrm{a}, \overline{b, c}$ means with different superscript within the same row differ significantly $(\mathrm{p}<0.05) \mathrm{SEM}=$ standard error of the means.
In Sacco Crude Protein Degradation of Differently Processed Acacia hockii: The crude protein (CP) degradability of the differently processed Acacia hockii is presented in table 2. There was significant $(\mathrm{p}<0.05)$ difference in the CP degradation among the treatments following the different processing techniques.

T1 (ensiled) had the higher CP degradability than T2 and $\mathrm{T} 3$ which were similar $(\mathrm{P}>0.05)$. There was no significant $(p>0.05)$ difference between the degradability of T2 (dried) and T3 (ensiled). The a soluble fraction(a) value obtained for all the treatments were significantly different from each other as shown in the table 4.1.

For crude protein, the insoluble but degradable fraction (b) value of $62.66 \%$ obtained for $\mathrm{T} 1$, was significantly $(\mathrm{p}<0.05)$ higher than those of $\mathrm{T} 2$ $(53.12 \%)$ and T3 (52.33\%) which were not significantly $(p>0.05)$ different from each other. In this study, the rate of CP degradation was significantly $(p<0.05)$ affected by processing methods with the highest value of $\mathrm{c}$ for T3 $(0.113 \mathrm{~h})$ and lowest for T1 (0.019h).

Insacco Neutral Detergent Fiber Degradation Studies: The neutral detergent fiber (NDF) degradability of the feed was presented in table 3 . There was a significant $(\mathrm{p}<0.05)$ difference in the NDF degradation following the different processing techniques. T1 (ensiled) had the highest $(p<0.05)$ ADF degradability followed by T3 (fresh) and then T2. The NDF soluble fraction (a) value (3.64\%) obtained in $\mathrm{T} 2$, was significantly $(\mathrm{p}<0.05)$ higher than those of $\mathrm{T} 1$ and T3 with $0.69 \%$ and $0.62 \%$ respectively which were not significantly $(\mathrm{p}>0.05)$ different from each other.For $\mathrm{b}$ (insoluble but degradable fraction), the NDF value (17.06\%) obtained for T1 was significantly $(\mathrm{p}<0.05)$ higher than those of T2 and T3 which values were 15.43 and $5.86 \%$ respectively which were also significantly $(\mathrm{p}<0.05)$ different from each other. In this study, the rate of NDF degradation was significantly $(\mathrm{p}<0.05)$ affected by processing methods with the highest value of $\mathrm{c}$ in $\mathrm{T} 1(0.315 \mathrm{~h})$ and lowest in T2 $(0.054 \mathrm{~h})$.

In Sacco Acid Detergent Fiber Degradation Studies of Differently Processed Acacia hockii: The acid detergent fiber (ADF) degradability of the feed is presented in table 4 . There was significant $(p<0.05)$ difference in the ADF degradation following the different processing techniques. T1 (ensiled) had the highest $(\mathrm{p}<0.05)$ ADF degradability followed by T3 (fresh). The degradability increased with the incubation hours from $6 \mathrm{~h}$ to $48 \mathrm{~h}$. 
Table 2. Effects of Processing on Degradation Characteristics and Disappearance of Crude Protein in Acacia hockii leaf

\begin{tabular}{|c|c|c|c|c|c|c|c|c|c|}
\hline \multicolumn{10}{|c|}{ Incubation time (h) } \\
\hline Treatments & 3 & 6 & 12 & 24 & 48 & $\mathbf{a}$ & B & $\mathbf{a}+\mathbf{b}$ & $\mathrm{C}$ \\
\hline T1(Ensiled) & $60.87^{\mathrm{a}}$ & $59.41^{b}$ & $62.51^{\mathrm{a}}$ & $59.23^{\mathrm{a}}$ & $53.10^{\mathrm{a}}$ & $55.31^{\mathrm{a}}$ & $62.66^{\mathrm{a}}$ & $117.97^{\mathrm{a}}$ & $0.019^{\mathrm{b}}$ \\
\hline T2(Dried) & $52.54^{\mathrm{b}}$ & $65.35^{\mathrm{a}}$ & $52.06^{\mathrm{b}}$ & $53.08^{b}$ & $52.13^{\mathrm{b}}$ & $46.44^{\mathrm{b}}$ & $53.12^{\mathrm{b}}$ & $99.56^{\mathrm{b}}$ & $0.023^{b}$ \\
\hline T3(Fresh) & $52.74^{\mathrm{b}}$ & $52.25^{\mathrm{c}}$ & $52.79^{\mathrm{b}}$ & $45.17^{\mathrm{c}}$ & $52.33^{\mathrm{b}}$ & $33.77^{\mathrm{c}}$ & $52.33^{\mathrm{b}}$ & $86.10^{\mathrm{c}}$ & $0.113^{\mathrm{a}}$ \\
\hline SEM & 0.852 & 0.378 & 0.561 & 0.861 & 0.470 & 1.722 & 0.719 & 2.346 & 0.005 \\
\hline
\end{tabular}

$\overline{a, b, c}$ means with different superscript within the same column differ significantly $(p<0.05)$ SEM $=$ standard error of the means. $a=$ soluble fraction, $b=$ insoluble fraction, $a+b=$ sum of soluble and insoluble fraction, $c=$ degradation rate constant .

Table 3. Effects of processing on degradation characteristics and disappearance of NDF in Acacia hockii leaf.

\begin{tabular}{llllllllll}
\hline \multicolumn{10}{c}{ Incubation time (h) } \\
\hline Treatments & $\mathbf{3}$ & $\mathbf{6}$ & $\mathbf{1 2}$ & $\mathbf{2 4}$ & $\mathbf{4 8}$ & $\mathbf{a}$ & $\mathbf{B}$ & $\mathbf{a}+\mathbf{b}$ & $\mathbf{C}$ \\
\hline T1(Ensiled) & $15.05^{\mathrm{a}}$ & $13.12^{\mathrm{a}}$ & $3.94^{\mathrm{b}}$ & $10.15^{\mathrm{a}}$ & $3.27^{\mathrm{c}}$ & $0.69^{\mathrm{b}}$ & $17.06^{\mathrm{a}}$ & $17.76^{\mathrm{b}}$ & $0.315^{\mathrm{a}}$ \\
T2(Dried) & $1.14^{\mathrm{c}}$ & $10.16^{\mathrm{b}}$ & $9.17^{\mathrm{a}}$ & $3.92^{\mathrm{c}}$ & $15.43^{\mathrm{a}}$ & $3.64^{\mathrm{a}}$ & $15.43^{\mathrm{b}}$ & $19.07^{\mathrm{a}}$ & $0.054^{\mathrm{c}}$ \\
T3(Fresh) & $12.00^{\mathrm{b}}$ & $11.73^{\mathrm{b}}$ & $4.50^{\mathrm{b}}$ & $6.16^{\mathrm{b}}$ & $5.86^{\mathrm{b}}$ & $0.62^{\mathrm{b}}$ & $5.86^{\mathrm{c}}$ & $6.48^{\mathrm{c}}$ & $0.217^{\mathrm{b}}$ \\
SEM & 0.449 & 0.965 & 0.353 & 2.308 & 1.547 & 1.020 & 1.548 & 0.629 & 0.028 \\
\hline
\end{tabular}

$a, b, c$ means with different superscript within the same column differ significantly $(p<0.05)$ SEM $=$ standard error of the means. $a=$ soluble fraction, $b=$ insoluble fraction, $a+b=$ sum of soluble and insoluble fraction, $c=$ degradation rate constant .

Table 4. Effects of processing on degradation characteristics and disappearance of ADF in Acacia hockii leaf

\begin{tabular}{|c|c|c|c|c|c|c|c|c|c|}
\hline \multicolumn{10}{|c|}{ Incubation time (h) } \\
\hline Treatments & 3 & 6 & 12 & 24 & 48 & $\mathbf{A}$ & $\mathbf{B}$ & $\mathbf{a}+\mathbf{b}$ & $\mathbf{C}$ \\
\hline T1(Ensiled) & $5.53^{\mathrm{a}}$ & $2.16^{\mathrm{b}}$ & $3.09^{\mathrm{a}}$ & $3.01^{\mathrm{a}}$ & $5.15^{\mathrm{b}}$ & $1.08^{\mathrm{a}}$ & $5.15^{\mathrm{a}}$ & $6.23^{\mathrm{b}}$ & $0.048^{\mathrm{b}}$ \\
\hline T2(Dried) & $1.08^{\mathrm{b}}$ & $3.67^{\mathrm{a}}$ & $0.78^{\mathrm{b}}$ & $2.61^{\mathrm{a}}$ & $6.29^{\mathrm{a}}$ & $1.39^{\mathrm{a}}$ & $4.95^{\mathrm{a}}$ & $6.34^{\mathrm{b}}$ & $0.084^{b}$ \\
\hline T3(Fresh) & $1.79^{\mathrm{b}}$ & $1.47^{\mathrm{c}}$ & $3.58^{\mathrm{a}}$ & $3.71^{\mathrm{a}}$ & $4.99^{\mathrm{b}}$ & $0.38^{\mathrm{b}}$ & $4.99^{\mathrm{a}}$ & $5.37^{\mathrm{a}}$ & $0.133^{\mathrm{a}}$ \\
\hline SEM & 1.400 & 0.943 & 1.098 & 1.294 & 1.733 & 0.344 & 1.845 & 1.853 & 0.041 \\
\hline
\end{tabular}

a,b,c means with different superscript within the same column differ significantly $(\mathrm{p}<0.05) \mathrm{SEM}=$ standard error of the means. a $=$ soluble fraction, $\mathrm{b}=$ insoluble fraction, $\mathrm{a}+\mathrm{b}=$ sum of soluble and insoluble fraction, $\mathrm{c}=$ degradation rate constant.

The soluble fraction (a) value $(0.38 \%)$ obtained in $\mathrm{T} 3$ for ADF degradability was significantly lower $(p<0.05)$ than those of T1 and T2 $(1.08$ and $1.39 \%)$ which were not significantly $(p>0.05)$ different from each other For $b$ (insoluble but degradable fraction) value $5.15 \%$ of obtained for the ADF degradability in T1 was significantly $(\mathrm{p}<0.05)$ higher than those of T2 and T3 with 4.95 and $4.99 \%$ respectively.

However, T2 and T3 were not significantly $(\mathrm{p}>0.05)$ different from each other. In this study, the rate of ADF degradation was significantly $(p<0.05)$ affected by processing methods with the highest value of $\mathrm{c}$ for T3 (0.113h) and lowest for T1 (0.048h)

Effective crude protein degradability of differently Processed Acacia hockii: Table 5 shows the effective crude protein degradability (ECPD) of differently processed Acacia hockii. There was significant $(p<0.05)$ difference among the three treatments for (ECPD) at the different passage rates.

Table 5. Effect of processing methods on different passage rates of $\mathrm{CP}$ in Acacia. Hockii leaf

\begin{tabular}{lllll}
\hline \multicolumn{5}{c}{ Passage rate/h } \\
\hline Treatments & $\mathbf{0 . 0 2}$ & $\mathbf{0 . 0 3}$ & $\mathbf{0 . 0 4}$ & $\mathbf{0 . 0 5}$ \\
\hline T1(Ensiled) & $86.32^{\mathrm{a}}$ & $80.26^{\mathrm{a}}$ & $76.25^{\mathrm{a}}$ & $73.41^{\mathrm{a}}$ \\
T2(Dried) & $74.22^{\mathrm{c}}$ & $68.97^{\mathrm{c}}$ & $65.39^{\mathrm{c}}$ & $62.81^{\mathrm{c}}$ \\
T3(Fresh) & $78.19^{\mathrm{b}}$ & $75.08^{\mathrm{b}}$ & $72.37^{\mathrm{b}}$ & $70.00^{\mathrm{b}}$ \\
$\mathrm{SEM}$ & 3.139 & 3.078 & 2.956 & 2.830 \\
\hline a,b, c means with different superscript within the same column \\
differ significantly $(\boldsymbol{p}<0.05)$ SEM = standard error of the means
\end{tabular}

The (ECPD) decreased with increase in outflow rates from $2 \%$ to $5 \%$. It ranged from $86.32 \%(\mathrm{~K}=0.02)$ for $\mathrm{T} 1$ to $62.81 \%(\mathrm{~K}=0.05) \mathrm{T} 2$. There were significant $(p<0.05)$ difference between the outflow rates of the treatments in which $\mathrm{T} 1$ (ensiled) had the highest outflow rates followed by the T3 (fresh) while T2 (dried) had the least.

Effective Acid Detergent Fiber Degradability: Table 6 show the effective acid detergent fiber degradability (EADFD). There was significant $(p<0.05)$ difference between the three treatments for EADFD. The (EADFD) decreased with increase in outflow rates from $2 \%$ to $5 \%$. It ranged from $6.25 \%(\mathrm{~K}=0.02)$ in $\mathrm{T} 1$ to $3.44 \%(\mathrm{~K}=0.05)$ in $\mathrm{T} 2$. There were significant $(p<0.05)$ difference between the outflow rates of the treatments in which $\mathrm{T} 1$ (ensiled) had the highest outflow rates followed by the T3 (fresh) while T2 (dried) had the least.

Table 6. Effect of processing methods on different passage rates of ADF in Acacia hockii leaf

\begin{tabular}{lllll}
\hline \multicolumn{5}{c}{ Passage rate/h } \\
\hline Treatments & $\mathbf{0 . 0 2}$ & $\mathbf{0 . 0 3}$ & $\mathbf{0 . 0 4}$ & $\mathbf{0 . 0 5}$ \\
\hline T1(Ensiled) & $6.25^{\mathrm{a}}$ & $5.90^{\mathrm{a}}$ & $5.58^{\mathrm{a}}$ & $5.31^{\mathrm{a}}$ \\
T2(Dried) & $4.35^{\mathrm{c}}$ & $3.94^{\mathrm{c}}$ & $3.66^{\mathrm{c}}$ & $3.44^{\mathrm{c}}$ \\
T3(Fresh) & $5.72^{\mathrm{b}}$ & $5.22^{\mathrm{b}}$ & $4.83^{\mathrm{b}}$ & $4.53^{\mathrm{b}}$ \\
SEM & 1.794 & 1.670 & 1.567 & 1.480 \\
\hline
\end{tabular}

$\mathrm{a}, \overline{b, c \text { means with different superscript within the same column }}$ differ significantly $(\mathrm{p}<0.05) \mathrm{SEM}=$ standard error of the means.

Effective Neutral Detergent Fiber Degradability of Differently processed Acacia Hocki: Table 7 .shows 
the effective neutral detergent fiber degradability (ENDFD) subjected different processing methods. There was significant $(\mathrm{p}<0.05)$ difference between the three treatments for ENDFD. The ENDFD also decreased with increase in outflow rates from $2 \%$ to $5 \%$. It ranges from $16.72 \%(\mathrm{~K}=0.02)$ for $\mathrm{T} 1$ to $5.54 \%$ $(\mathrm{K}=0.05)$ for $\mathrm{T} 3$. There was significant $(\mathrm{p}<0.05)$ difference among the outflow rates of the treatments in which T1 (ensiled) had the highest outflow rates followed by the T2 (dried) while T3 (fresh) had the least.

Table 7. Effect of processing methods on different passage rates of NDF in Acacia hockii leaf

\begin{tabular}{lllll}
\hline & \multicolumn{4}{c}{ Passage rate/h } \\
\hline Treatments & $\mathbf{0 . 0 2}$ & $\mathbf{0 . 0 3}$ & $\mathbf{0 . 0 4}$ & $\mathbf{0 . 0 5}$ \\
\hline T1(Ensiled) & $16.72^{\mathrm{a}}$ & $16.26^{\mathrm{a}}$ & $15.81^{\mathrm{a}}$ & $15.40^{\mathrm{a}}$ \\
T2(Dried) & $14.89^{\mathrm{b}}$ & $13.46^{\mathrm{b}}$ & $12.52^{\mathrm{b}}$ & $11.68^{\mathrm{b}}$ \\
T3(Fresh) & $6.17^{\mathrm{c}}$ & $5.94^{\mathrm{c}}$ & $5.73^{\mathrm{c}}$ & $5.54^{\mathrm{c}}$ \\
SEM & 0.606 & 0.603 & 0.604 & 0.609 \\
\hline
\end{tabular}

a,b,c means with different superscript within the same column differ significantly $(\mathrm{p}<0.05) \mathrm{SEM}=$ standard error of the means.

In Sacco Crude Protein Degradation of Differently Processed Acacia hockii: The higher crude protein degradability in the ensiled leaf might be due to differences in their chemical composition and the processing methods accessioned by the activities of microorganisms during ensiling. The improved degradation of crude protein in study could be due to the reduced anti-nutritional content of the processed Acacia hockii leaf by ensiling and drying which granted the rumen microorganisms more access to the crude protein of the processed leaf.. Anti-nutritional factors inhibit plant protein degradation and decrease sulphur availability in the rumen, which in turn affect the digestibility of total tract nitrogen (Makkar et al., 2003) and plant cell walls (Amital, 2014). These tannins inhibit microbial enzymes in the rumen and decrease the availability of plant proteins for digestion in the intestines. Therefore, the anti-nutritional factors could be reduced through ensiling and drying thereby increase the plant protein degradation. The difference in solubility might be due to difference in fibre content of the feeds. The rate of degradation (c) is important in the assessment of the fermentation in the rumen (Preston, 1986).This might be due to differences in their chemical composition and the processing methods. Low NDF content (20 to 35\%) has been shown to result in high digestibility, while lignification's of the plant cell wall decrease the digestibility of plant material in the rumen. The low degradability of forages with high ADF and tannin is due to reduced penetrative ability to rumen microbes through lignified plant cell walls and precipitations effects of anti-nutritional factors to microbes and enzymes as reported by (Makkar et al., 2003, Baloyi et al., 2008). Therefore, the ADF and NDF degradability increase with decrease in the antinutritional factors which was achieved through ensiling and drying in the study. The difference in solubility characteristics might be due to difference in fibre content of the feeds. The degradability decreased with the incubation hours from $3 \mathrm{~h}$ to $48 \mathrm{~h}$. This might be due to differences in the processing methods and the physiological condition of the experimental animals.

Conclusion: It can be concluded from the study that ensiling and drying methods of processing of the Acacia hocki leaf reduced the anit-nutritional factors which then made nutrients in the leaf to become more degradable by rumen micro-organisms. However, the results of the study also revealed that ensiling is more effective than drying in reducing the anti-nutritional factors, hence better degradability of the ensiled leaf.

\section{REFERENCES}

AmitaI, A (2014).The use of non-conventional feed resources for Livestock feeding in the tropics: a review. J. Global Bio sci. 3(2), 604-613.

AOAC. (2000). Official Methods of Analysis. 15th ed. Association of Analytical Chemists,

Azim, A; Khan, AG; Ahmad, J; Ayaz, M; and Mirza, $\mathrm{H}$ (2002). Nutrition evaluation of fodder tree leaves with goats. Asian-Australasian J. Ani. Sci. 15(1): 34-37.

Baloyi, JJ; Ngongoni, NT; Hamudi, kH (2008). Chemical composition and Ruminal Degradability of Cow pea and silver leaf desmodium forage legumes harvested at different stages of maturity. Tropical And Sub tropical agro ecosystems 8

Climate-data.org (2019). Climate Katsina. https://www.enclimate-data.org/africa/nogeria. Assessed on $30^{\text {th }}$ febuary, 2020.

Duncan, RF (1995). Cordycepin blocks recovery of non-heat-shock mRNA translation following heat shock in Drosophila. Europ. J. Biochem. 233(3): 784--792.

Fageria, NK (1997). Growth and Mineral Nutrition of Field Crops. NY, NY: Marcel Dekker. .p595.

Hoste, H; Jackson, F; Athanasiadou, S; Thamsborg, SM; Hoskin, SO (2006). The effects of tannin rich plants on parasitic nematodes in ruminants. Trends parasitol. 22:253-261.

Kamatali, P; Teller, E; Vanbelle, M; Collignon, G; Foulon, M (1992). Insitu degradability of organic 
matter, crude protein and cell walls of various tree forages. Ani Prod. 55: 29-34.

Kamra, DN; Patra, AK; Chatteerjee, PN; Kumar, R; Agarwal, N (2008). Effect of plant extracts on methanogenesis and microbial profile of the rumen of buffalo: a brief overview. Austr J. Exp Agric. 48:175-78.

Khamseekhiew, B; Juan, L; Choi, W; Jelan, ZA (2001). Ruminal and Intestinal Digestibility of Some Tropical Legume Forages. 14:p.321

Makkar, HPS (2003). Effect sand fate of condensed tannins In ruminant animals, adaptation to condensed tannins, 49:241-256.

Meteoblue weather (2017). Climate Katsina. https://www.meteoblue.com/en/weather/forecast/ model climate/katsina nigeria_2334802 Assessed on $30^{\text {th }}$ February, 2020.

Orden, EA; Abdulrazak, SA; Cruz, EM; Orden, MEM; Ichinohe, T; Fujihara, T (2000). Leucaena leucocephala and Gliricidia sepium supplementation in sheep fed with ammonia treated rice straw: Effect on intake, digestibility, microbial protein yield and live-weight changes. Asian-Austria. J. Anim. Sci. 13 (12): 1659-1666.
Ørskov, ER (2000). The In situ technique for estimation of forage degradability in ruminants. Forage Evaluation in Ruminant Nutrition (Edited by D I Givens, E Owen, Axford, R F E and Omed H M) CAB International, Wallingford pp 175-188

Preston, TR (1986). Better utilization of crop residues and byproducts in animal feeding: research guidelines 2. A practical manual for research workers.

http://www.fao.org/DOCREP/003/X6554E/X655 $\underline{4 \mathrm{E} 0 . \mathrm{HTM}}$

Scott,. C; Alain, A; Damase, K; Ann, D (2013). Tropical Agroforestry. Springer Science \& Business Media. p. 11. ISBN 978-94-007-7723-1

Statistical Analysis System (2001) User's Guide: Statistics, Version 8.2. SAS Institute, NC, USA. Washington DC., 